\section{Impact of Kaolin Particle Film and Water Deficit on Wine Grape Water Use Efficiency and Plant Water Relations}

\author{
D. Michael Glenn² \\ U.S. Department of Agriculture, Agricultural Research Service, Appalachian \\ Fruit Research Station, 2217 Wiltshire Road, Kearneysville, WV 25430
}

Nicola Cooley ${ }^{1}$, Rob Walker, and Peter Clingeleffer
CSIRO Plant Industry, Private Mail Bag, Merbein, Victoria, Australia 3505

Krista Shellie

U.S. Department of Agriculture, Agricultural Research Service, Horticultural Crops Research Laboratory, 29603 U of I Lane, Parma, ID 83660

Additional index words. Vitis vinifera, water stress, heat stress, vegetative growth, canopy-air temperature

\begin{abstract}
Water use efficiency (WUE) and response of grape vines (Vitis vinifera $\mathrm{L}$. cvs. 'Cabernet Sauvignon', 'Merlot', and 'Viognier') to a particle film treatment (PFT) under varying levels of applied water were evaluated in Victoria, Australia, and southwestern Idaho. Vines that received the least amount of water had the warmest canopy or leaf surface temperature and the lowest (more negative) leaf water potential, stomatal conductance $\left(g_{S}\right)$, transpiration $(E)$, and photosynthesis $(A)$. Vines with plus-PFT had cooler leaf and canopy temperature than non-PFT vines; however, temperature difference resulting from irrigation was greater than that resulting from PFT. In wellwatered vines, particle film application increased leaf water potential and lowered $g_{\mathrm{S}}$. Point-in-time measurements of WUE (A/E) and $g_{\mathrm{S}}$ did not consistently correspond with seasonal estimates of WUE based on carbon isotope discrimination of leaf or shoot tissue. The response of vines with particle film to undergo stomatal closure and increase leaf water potential conserved water and enhanced WUE under nonlimiting soil moisture conditions and the magnitude of response differed according to cultivar.
\end{abstract}

Received for publication 2 Apr. 2010. Accepted for publication 13 June 2010.

The project was funded in part by the Cooperative Research Centre for Viticulture, and the Grape and Wine Research and Development Corporation. The research was a collaboration between USDA-ARS Kearneysville, WV, and Parma, ID, and CSIRO Plant Industry.

We thank Jeff Milne, Craig Thornton, and Justin McPhee of the Wingara Wine Group, Australia, for allowing us to use their vineyard and for being very supportive throughout the experiment. We acknowledge Damien Watson and Rachel Hanlin for their assistance in the vineyard for the Australian component of the project. We also thank Dr. Everard Edwards who assisted with the evapotranspiration data collection and calculations for CSIRO Plant Industry.

Mention of a trademark, proprietary product, or vendor does not constitute a guarantee or warranty of the product by the U.S. Dept. of Agriculture and does not imply its approval to the exclusion of other products or vendors that also may be suitable.

${ }^{1}$ Current address: University of Melbourne, Dookie College, Victoria, 3647, Australia.

${ }^{2}$ To whom reprint requests should be addressed; e-mail michael.glenn@ars.usda.gov.
(Hardie and Martin, 1990; Kriedemann and Goodwin, 2003). RDI is a common viticultural practice for production of red wine grapes in arid and semiarid production regions (Greenspan, 2005) and the strategy is based on the work of Hardie and Considine (1976) who documented different responses to water-deficit stress when imposed before or after veraison. Vine water stress has its greatest influence on berry and canopy size when it is imposed before veraison (Matthews and Anderson, 1988; Matthews et al., 1987; McCarthy, 1997) and this stage may also affect berry mass components (Roby et al., 2004; Roby and Matthews, 2004) and secondary metabolites associated with wine quality (Cortell et al., 2005; Hrazdina et al., 1984). Study results are inconsistent regarding how RDI affects fruit maturity and vine reproductive capacity and results are difficult if not impossible to compare because they do not report a common biological indicator of water stress severity (Buttrose, 1974; Esteban et al., 1999; Hepner et al., 1985; Matthews and Anderson, 1988; Matthews et al., 1987; Salon et al., 2005).

Vine water deficit during Stage I of berry development may continue to impact vine growth processes after alleviation and recovery of water stress. Water deficit alters carbon partitioning (Bota et al., 2001), which can result in less floral initiation (Meriaux et al., 1979), reduced leaf area, and reduced shoot and root growth and development (Boland et al., 2000a, 2000b). Changes in root growth and development may subsequently influence soil water extraction and translocation of root-derived signals (Rogiers et al., 2010). Moriana et al. (2003) found that the leaf water potential and stomatal conductance $\left(g_{\mathrm{S}}\right)$ of olive subjected to short-term RDI never returned to fully irrigated control levels until the end of the season. In contrast, Boland et al. (2000b) documented full recovery of peach leaf water potentials in RDI treatments after full irrigation suggesting that species and site interactions impact recovery from RDI in addition to experimental differences.

RDI results in higher canopy light transmission (Shellie, 2006) that may lead to undesirable fruit exposure and sunburn in warm production regions with high solar radiation (Tarara et al., 2008; Wample, 1996). A porous kaolin-particle film on a leaf or fruit surface (PFT) has been shown to reduce heat stress without restricting gas exchange (Glenn, 2009; Glenn et al., 2001). The leaf is able to intercept photosynthetically active radiation through the particle film, but the film reflects ultraviolet and infrared (IR) radiation from the surface (Glenn and Puterka, 2005). The particle film reduced leaf temperature and resulted in a net diurnal increase in $g_{S}$ in apple (Glenn et al., 2001) and wine grape (Shellie and Glenn, 2008) but had no influence on wine grape midday leaf water potential (Shellie and Glenn, 2008). Water use efficiency (WUE), defined as unit of assimilated carbon per unit of transpiration, was increased in citrus (Jifon and Syvertsen, 2003) and decreased in apple (Glenn, 2010; Glenn et al., 2003) by the use of PFT 
suggesting an interaction of PFT with species or other climatic or edaphic factors. The purpose of this study was to examine how application of PFT and severity of pre-veraison water stress impacted post-veraison leaf water potential, canopy temperature, gas exchange, berry characteristics, and WUE.

\section{Materials and Methods}

Field trials were conducted on own-rooted 'Cabernet Sauvignon' grape (Vitis vinifera L.) in a commercial vineyard (Wingara Wine Group) in the Sunraysia region of Victoria, Australia (lat. $34^{\circ} 13^{\prime}$ S, long. $142^{\circ} 4^{\prime} \mathrm{E}$, elevation $52 \mathrm{~m}$ ) in 2003 and on own-rooted 'Merlot' (U.C. Davis Foundation Plant Services clone 1) and 'Viognier' (U.C. Davis Foundation Plant Services clone 1) in the Western Snake River Plain of Idaho (University of Idaho, Parma Research and Extension Center, lat. $43^{\circ} 49^{\prime} \mathrm{N}$, long. $116^{\circ} 56^{\prime} \mathrm{W}$, elevation $750 \mathrm{~m}$ ) in 2005 . Both vineyard sites are located in semiarid winter rainfall zones.

Replicated field plots at each trial site were supplied a percentage of their estimated evapotranspiration (ET) requirements through above-ground drip emitters. The irrigation treatment levels were allocated randomly to plots in a blocked design with two (Idaho) or 12 (Victoria) replications. Subplots, nested within each irrigation main plot, contained an equal number of vines (two in Australia, four in Idaho) that either received a foliar particle film treatment (plus-PFT) (Surround WP'M; NovaSource, a division of Tessenderlo Kerley Inc., Phoenix, AZ, formerly Engelhard Corp., Iselin, NJ) during Stage I of berry development or were left untreated (non-PFT). Application rate was 3\% (Victoria) or $6 \%$ (Idaho) PFT material. Surround WPTM is based on kaolin, a white, non-porous, non-swelling, low-abrasive, fine-grained, plate-shaped, aluminosilicate mineral $\left[\mathrm{Al}_{4} \mathrm{Si}_{4} \mathrm{O}_{10}(\mathrm{OH})_{8}\right]$ that easily disperses in water and is chemically inert over a wide $\mathrm{pH}$ range. The Surround $\mathrm{WP}^{\mathrm{TM}}$ formulation contains $5 \%$ adjuvants to aid spreading and adhesion of the particles.

The vines at both sites were vertically trained, although pruning style differed. With the exception of irrigation scheduling and PFT, vines were managed according to standard commercial practice, which included weed removal, pesticide application, and nutrient management.

The irrigation regimes provided an amount of supplemental water that met either $100 \%$ of estimated crop evapotranspiration $\left(\mathrm{ET}_{\mathrm{c}}\right)$ throughout the growing season or a reduced percentage of $\mathrm{ET}_{\mathrm{c}}$ beginning shortly after fruit set. When approximately half of all fruit on the vine were at veraison (the phenological stage defined here as a change in berry color from green to red), the preveraison water deficit was either alleviated (Idaho) or eliminated (Victoria). The specific deficit percentages and their corresponding phenological timing are described subsequently under each trial location.

Plot soil moisture was monitored biweekly in Victoria at multiple depths (10-cm intervals to a depth of $1.2 \mathrm{~m}$ ) with a neutron probe. There were six tubes (two per treatment) positioned under the drip line midway between two treatment vines, i.e., Vines 5 to 6 of the eight-vine plot. Physiological measurements included leaf water potential, $g_{\mathrm{S}}$, leaf temperature, and leaf transpiration near or after veraison. Fruit sampled at commercial maturity was evaluated for standard indicators of quality, including soluble solids concentration (temperature corrected refractometer), $\mathrm{pH}$ ( $\mathrm{pH}$ electrode), titratable acidity $(0.2 \mathrm{~N} \mathrm{NaOH}$ to $\mathrm{pH}$ end point of 8.2), average berry weight, cluster weight, and yield per vine. Methods used are detailed subsequently under each trial location.

'Cabernet Sauvignon', Sunraysia region, Victoria, Australia, 2003-2004 season. Soil type at this site was a Nookamka sandy loam (Penman et al., 1939). Vines were planted in 1995 with a $3 \times 2.4-m$ row-by-vine spacing (1389 vines/ha). Vines were minimally pruned, cordon-trained to a two-wire vertical trellis with wires at 1.5 and $1.8 \mathrm{~m}$, and were mechanically hedged (retaining $\approx 150$ buds per vine). Drip emitters spaced every $0.6 \mathrm{~m}$ delivered $4 \mathrm{~L} \cdot \mathrm{h}^{-1}$. Three irrigation treatments were imposed: 1) an irrigated control (STD) maintained throughout the season by soil water replenishment based on neutron-probe data readings and with set points determined from soil water use data of previous seasons (hereafter referred to as $100 \%$ of estimated $\left.\mathrm{ET}_{\mathrm{c}} ; 2\right)$ a RDI that received $100 \% \mathrm{ET}_{\mathrm{c}}$ until completion of fruit set (25 Nov. 2003) followed by $50 \%$ of $\mathrm{ET}_{\mathrm{c}}$ until the end of berry development Stage I (2 Jan.) and then 100\% $\mathrm{ET}_{\mathrm{c}}$ until harvest (15 Mar.); and 3) a prolonged deficit treatment (PD) that was identical to the RDI treatment except that supplemental water was entirely withheld for $14 \mathrm{~d}$ at the end of berry development stage I. This withholding period corresponded with the onset of berry lag phase (4 Jan.) and ended when approximately half of the fruit had reached veraison (18 Jan.). Seasonal reference $\mathrm{ET}_{\mathrm{c}}$ was $1355 \mathrm{~mm}$ calculated according to Allen et al. (1998) using meteorological data collected at Mildura, $\approx 35 \mathrm{~km}$ from the Wingara site. Irrigation amounts were: $6.4 \mathrm{~mL} \cdot \mathrm{ha}^{-1}, 5.1 \mathrm{~mL} \cdot \mathrm{ha}^{-1}$, and $4.9 \mathrm{~mL} \cdot \mathrm{ha}^{-1}$ for the $100 \% \mathrm{ET}_{\mathrm{c}}, \mathrm{RDI}$, and PD treatments, respectively.

The experimental design was a split plot with three irrigation treatments (main plot), two particle film levels (subplot), and 12 replicate blocks. Each irrigation main plot contained three rows of 12 vines per row with data collected from the center row of each plot. Non-PFT and plus-PFT subplots were established within each irrigation main plot. The subplots contained two adjacent, untreated control vines (non-PFT) and two adjacent plus-PFT-treated vines. The plusPFT vines received four spray applications. The first two applications, applied $14 \mathrm{~d}$ apart (on 28 Nov. and 12 Dec. 2003), coincided with onset of the first deficit irrigation regime, which began just after fruit set (28 Nov.). Subsequent applications re-established the particle film after rainfall, during berry de- velopment Stage I and the lag phase (23 Dec. and 5 Jan. 2004). The leaf residue amounts were 1 to $2 \mathrm{~g} \cdot \mathrm{m}^{-2}$.

Three of the 12 block replicates were instrumented with sensors when vines were near verasion (4 Jan.). Thermocouple psychrometers (Model 75; J.R.D. Merrill, Logan, UT) were attached to interior shaded leaves of each vine using a clamp similar to Campbell and Campbell (1974). The thermocouple psychrometer sensors were individually calibrated against a salt solution of -2.2 $\mathrm{MPa}$ at $25{ }^{\circ} \mathrm{C}$. The psychrometers were attached to the abaxial, midvein region of the leaf and the leaf surface was not abraded (Campbell and Campbell, 1974; Campbell and McInnes, 1999). The psychrometers were placed on new leaves every 2 weeks. Three replicates of plus-PFT versus non-PFT for each irrigation treatment were instrumented with two thermocouple psychrometers per plant. Twelve thermocouple psychrometers were installed in a replicate block. Interior shaded leaves were selected because they best reflect plant water status, similar to stem water potential measured with a pressure chamber using covered leaves (Begg and Turner, 1970; Chone et al., 2001; Goldhamer and Fereres, 2001) and to minimize thermal gradients from direct illumination. Shaded leaf water potential (SLWP) was measured hourly and the mean SLWP from 1000 to 1600 HR was calculated as a measure of daily plant water status. SLWP before 1000 and after 1600 HR could receive direct illumination as a result of the low sun angle and so were excluded.

Canopy temperatures of the subplots (non-PFT and plus-PFT) in three irrigation treatments were measured with IR temperature transducers (Model IRTS; Apogee Instruments Inc., Logan, UT) located $30 \mathrm{~cm}$ above the canopy at a $30^{\circ}$ angle from horizontal. Six IR transducers were installed in a single replicate block. Air temperature was measured with a non-aspirated, shaded thermocouple attached to each IR temperature transducer. The IR temperature transducer was oriented in a northerly direction parallel with the canopy row to prevent shading of the canopy by the IR temperature transducers. Data were collected by a data logger (Model CR7; Campbell Scientific, Logan, UT) located in each replicate, for 20 time periods, 2 to $3 \mathrm{~d}$ per week from January to March.

The difference between canopy temperature and air temperature $(\Delta \mathrm{T})$ at the hour of maximum air temperature within each plot was calculated from the IR temperature transducers and its associated thermocouple. The relationship of $\Delta \mathrm{T}$ with maximum daily air temperature (MDAT) for each treatment was analyzed by linear regression with analysis of covariance in which $\Delta \mathrm{T}$ was the response variable and MDAT was the covariate. If irrigation treatments were not significantly different ( $P \leq 0.05$, unless noted otherwise), the data were pooled and reanalyzed against the remaining treatments. Treatment differences in SLWP values were analyzed in a split-split plot analysis in which sampling 
time was the main plot and irrigation treatment was the subplot and PFT application was the split-split plot. There was a three-way interaction indicating different responses before and after veraison; therefore, the data were reanalyzed for the pre- and post-veraison periods.

Transpiration (E), A, WUE (A/E) and $g_{\mathrm{S}}$ were measured during veraison (13 Jan. and 22 Jan.) and at the beginning of berry ripening (3 Feb. 2004) using a CIRAS-1 Photosynthesis System (PP Systems, Amesbury, MA). A single exposed leaf per plot $(\mathrm{n}=12)$ was measured within $1 \mathrm{~h}$ of solar noon. Data were analyzed in a split plot design by date with irrigation treatment as the main plot and PFT treatment as the subplot.

Five exposed leaves per vine from the fifth leaf position were collected from the 12 replicate blocks. The plant material was dried at $70{ }^{\circ} \mathrm{C}$ for $24 \mathrm{~h}$ or until a constant weight was measured. The dried and ground leaf tissue was analyzed for carbon-13 content (CSIRO Plant Industry Laboratory, Canberra, Australia). The isotopic carbon discrimination value $\Delta$ was calculated according to Farquhar et al. (1989). The isotopic composition of carbon dioxide in air was assumed to be -7.8 parts per thousand (Francey et al., 1995). $\Delta$ was used as a measure of seasonal WUE in which $\Delta$ is inversely related to seasonal WUE (Bacon, 2004; Bongi et al., 1994; Condon et al., 1990; Glenn et al., 2000; Jones, 2004).

Grape clusters from each vine (located in a 1-m wide transect) were collected (15 Mar. 2004) immediately before the commercial harvest of the block to estimate yield. Berry soluble solids concentration at harvest was $24.5{ }^{\circ}$ Brix. Five clusters per vine were randomly collected and soluble solids concentration was determined using the juice from a 100-berry sample (temperature compensating digital refractometer; Atago, Tokyo, Japan).

'Merlot' and 'Viognier', Parma, ID, 2005 season. The soil type at this site was a Turbyfill, fine sandy loam (U.S. Dept. Agric. Soil Conservation Service, 1972). Vines were planted in 1999 with a $2.7 \times 2.1$-m row-byvine spacing (1764 vines/ha). Each vine was double-trunked with each trunk forming a unilateral, 90-cm long cordon located $1 \mathrm{~m}$ above the soil surface. Cordon arms were spur-pruned to $\approx 30$ buds per vine (seven twobud spurs per cordon) and vertically trained using two sets of moveable wires. Drip emitters spaced $15 \mathrm{~cm}$ on either side of the vine trunk delivered $3.8 \mathrm{~L} \cdot \mathrm{h}^{-1}$. Two irrigation treatment levels were imposed: 1) An irrigated control (STD) estimated to provide $100 \% \mathrm{ET}_{\mathrm{c}}$ from fruit set until harvest; and 2) a PD irrigation that received $100 \% \mathrm{ET}_{\mathrm{c}}$ until completion of fruit set (20 June) followed by $35 \%$ of $\mathrm{ET}_{\mathrm{c}}$ until veraison (16 Aug.) and then $70 \% \mathrm{ET}_{\mathrm{c}}$ until harvest (27 Sept.). Seasonal, alfalfa-based $\mathrm{ET}_{\mathrm{c}}$ was $1197.6 \mathrm{~mm}$ (Allen et al., 1998) and weekly irrigation amount was calculated from $\mathrm{ET}_{\mathrm{c}}$ obtained from the U.S. Bureau of Reclamation Parma weather station (http://www.usbr.gov/pn/ agrimet/wxdata.html), a variable wine grape crop coefficient (Evans et al., 1993) and the desired percentage of $\mathrm{ET}_{\mathrm{c}}$. Seasonal irrigation amounts were $344.6 \mathrm{~mm}$ and $154.7 \mathrm{~mm}$ for the STD and PD treatments, respectively.

The experimental design was a split plot with two irrigation treatment levels (main plot), two particle film levels (subplot), and two replicates. Each irrigation main plot contained eight contiguous vines of each cultivar randomly located within three vine rows with 56 vines per row. Non-PFT and plus-PFT subplots were established within each irrigation main plot. The subplots contained four adjacent, untreated control vines (non-PFT) and two adjacent plus-PFT treated vines. The plus-PFT vines received four spray applications at a rate of $60 \mathrm{~g} \cdot \mathrm{L}^{-1}$ : the first three applied at weekly intervals just after fruit set $(6,11$, and 18 July) and coincided with onset of the first deficit irrigation regime. A subsequent application re-established the particle film post-veraison (8 Aug.).

Vine water status was monitored weekly pre- and post-veraison by measuring midday leaf water potential $\left(\Psi_{\mathrm{md}}\right)$ on Day 6 after each weekly irrigation. Two fully exposed, mature leaves showing no visible sign of damage were randomly selected from interior vines of each subplot within $1 \mathrm{~h}$ after solar noon. Leaves were covered with a clear plastic bag before severing the petiole at the point of shoot attachment and the bag containing the leaf was immediately inserted into a pressure chamber (PMS Instruments Model 610, Corvallis, OR). The chamber was pressurized at a rate of $33 \mathrm{kPa} \cdot \mathrm{s}^{-1}$ and balancing pressure was recorded at the first appearance of moisture on the cut petiole. The $g_{\mathrm{S}}$, leaf surface temperature (LI-1600 Steady State Porometer; LI-COR, Lincoln, NE), and leaf water potential $(\Psi)$ of four leaves per vine in each subplot were measured post-veraison on an hourly basis throughout the day. 'Merlot' was measured on 3 Aug. (2 weeks before veraison) and 'Viognier' was measured on 24 Aug. (6 d after veraison).

Yield per vine and average cluster weight were measured at harvest by counting and weighing total number of clusters per vine and dividing crop weight per vine by number of clusters. Average berry weight and must composition were determined at harvest from a sample of 10 clusters equally harvested from either side of the canopy. Berry weight was estimated from a 100-berry sample obtained from each of five locations (four cardinal quadrants and center) per cluster. The 10-cluster sample was passed through a hand-operated crusher, left refrigerated with the berry skins overnight, and analyzed at room temperature the next day for percent soluble solids, $\mathrm{pH}$, and titratable acidity (Shellie, 2006). Weekly and diurnal mean values for $\Psi_{\mathrm{md}}$ and $g_{\mathrm{S}}$ were measured. Data describing berry and vine attributes were analyzed separately by cultivar using analysis of variance appropriate for a block design (General Linear Model, SAS Version 8.02; SAS Institute, Cary, NC) with irrigation and particle film technology as main effects.
Probability of significant difference among treatments was determined from an $\mathrm{F}$ test. Significant $(P \leq 0.05)$ irrigation treatment means were separated using Duncan's multiple range test $(P \leq 0.05)$.

Five shoots per vine of each cultivar were collected from two replicate blocks after leaf fall and dried at $70{ }^{\circ} \mathrm{C}$ for $24 \mathrm{~h}$ until a constant weight was measured. The dried and ground tissue was analyzed for carbon-13 content (Isotope Services, Los Alamos, NM) and the isotopic carbon discrimination value $(\Delta)$ was calculated according to Farquhar et al. (1989), as described previously. $\Delta$ data were analyzed by cultivar to ascertain cultivar differences and, because none was detected, data were pooled for subsequent analyses. $\Delta$ data were analyzed in a split plot design with irrigation regime (STD versus PD) as the main plot and PFT $( \pm$ PFT $)$ as the subplot. When irrigation by PFT interaction was significant, means were separated using a protected least significant difference $(P \leq 0.05)$.

\section{Results}

'Cabernet Sauvignon', Sunraysia region, Victoria, Australia, 2003-2004 season. Irrigation amounts applied during the RDI period ( 25 Nov. 2003 to 2 Jan. 2004) were 134, 67 , and $67 \mathrm{~mm}$, respectively, for the STD, RDI, and PD treatments. Irrigation amounts applied during the PD period (4 Jan. 2004 to 18 Jan. 2004) were 42,42 , and $0 \mathrm{~mm}$, respectively, for STD, RDI, and PD treatments.

Phenology. In the 2003-2004 growing season, bud burst was complete by 10 Oct. 2003. Veraison duration was $22 \mathrm{~d}$ with $50 \%$ on $20 \mathrm{Jan}$. and $100 \%$ color change by 2 Feb. (115 d after bud break). Total soluble solids (TSS) was $10^{\circ}$ Brix on the 19 Jan. Vines were harvested on the 15 Mar. when mean TSS was $24.4^{\circ}$ Brix.

Vine canopy temperature status. The magnitude of $\Delta \mathrm{T}$ increased with MDAT for all irrigation strategies (Fig. 1A-D) in a manner similar to Jackson (1982) in which $\Delta \mathrm{T}$ increased in magnitude as the vapor pressure gradient increased. The magnitude of $\Delta \mathrm{T}$ was significantly greater for the plus-PFT treatments in each irrigation regime. The regression relationship of $\Delta \mathrm{T}$ with MDAT pre-veraison when STD, RDI, and PD treatments received $100 \%, 100 \%$, and $0 \%$ of $\mathrm{ET}_{\mathrm{c}}$, respectively, was not significantly different $(P \leq 0.05)$ from post-veraison when the RDI and PD irrigations received $100 \%$ of $\mathrm{ET}_{\mathrm{c}}$ (Fig. 1A-D); therefore, pre- and post-veraison data were pooled. The PD response of $\Delta \mathrm{T}$ with MDAT was the only relationship to have $\Delta \mathrm{T}$ values $0{ }^{\circ} \mathrm{C}$ or greater, which occurred during the pre-veraison $0 \% \mathrm{ET}_{\mathrm{c}}$ period and $4 \mathrm{~d}$ after with full irrigation (Figs. 1A and D). The regression relationship of $\Delta \mathrm{T}$ with MDAT was not significantly different between the STD and RDI treatments, but the PD regression was significantly different from the pooled STD and RDI treatments for the non-PFT treatments (Fig. 1A). The regression relationship of $\Delta \mathrm{T}$ with MDAT for the irrigation plus-PFT treatments indicated 

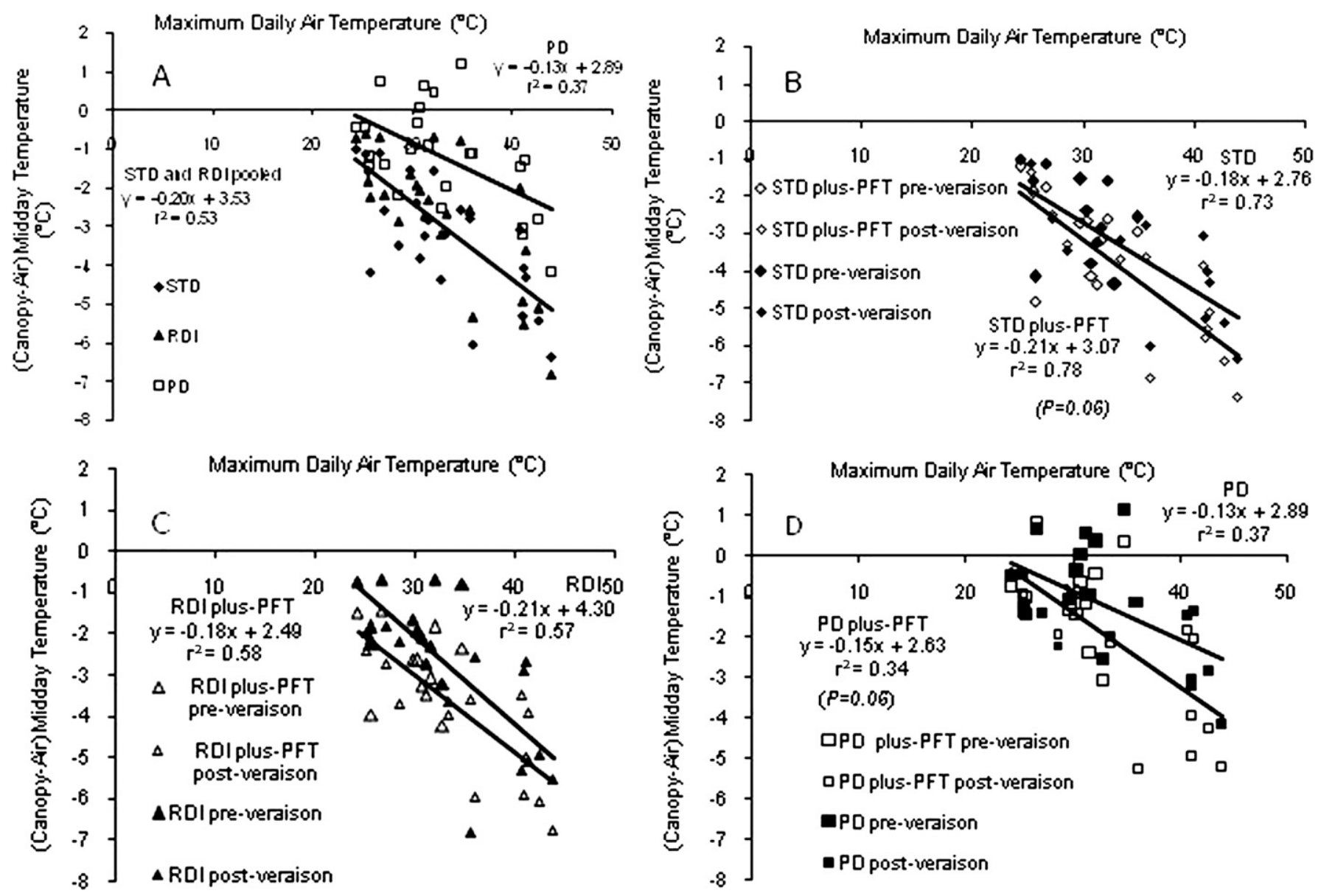

Fig. 1. Relationship between maximum daily ambient air temperature of 'Cabernet Sauvignon' grape (Vitis vinifera L.) grown in Victoria, Australia, under three irrigation treatments with (plus-PFT) or without (non-PFT) particle film treatment and the difference of vine canopy and ambient air temperature $(\Delta \mathrm{T})$, where (A) illustrates all irrigation treatments without PFT and other figures illustrate pre- and post-veraison, plus- or non-PFT, under (B) standard (STD), (C) regulated deficit irrigation (RDI), or (D) prolonged deficit (PD). The level of statistical significance is $P=0.05$ unless otherwise noted.

significant differences in comparison with all the non-PFT irrigation treatments (Fig. 1B-D).

Vine water status. SLWP was not correlated to mean daily air temperature (data not shown) indicating that temperature corrections and temperature gradients within the psychrometer chambers were not a significant error $(r=0.09, \mathrm{n}=168)$ (Campbell and Campbell, 1974). Analysis of variance (ANOVA) of pre-veraison SLWP indicated an irrigation by PFT treatment interaction in which the non-PFT RDI had significantly more negative SLWP compared with other treatments (Table 1). ANOVA of the postveraison SLWP did not indicate any two- or three-way interactions. Averaged over PFT treatments, the STD irrigation treatment had significantly less negative SLWP than the RDI or PD treatments $(-0.33,-0.61$, and -0.55 , respectively; $P=0.05)$. The application of PFT to irrigation treatments resulted in less negative SLWP after veraison in all irrigation treatments (Table 1).

Leaf gas exchange and water use efficiency: prolonged deficit stress period 13 Jan. 2004. At this sampling date, the STD and RDI irrigation level was $100 \%$ of $\mathrm{ET}_{\mathrm{c}}$ and the $\mathrm{PD}$ received $0 \% \mathrm{ET}_{\mathrm{c}}$. There was an irrigation by PFT interaction of E and A (Table 2). The
PD plus-PFT treatment had significantly lower E and A than the PD alone. The STD treatment had greater $g_{\mathrm{S}}, \mathrm{E}$, and $\mathrm{A}$ than the RDI and PD treatments with and without PFT. WUE (A/E) was unaffected by treatments.

Post-prolonged deficit stress period 22 Jan. 2004. There were no interactions when all treatments had resumed $100 \% \mathrm{ET}_{\mathrm{c}}$ replacement for $4 \mathrm{~d}$ (Table 2). On this date, the STD irrigation treatment had the highest E, A, $g_{\mathrm{S}}$ and WUE, whereas the PD treatment had the lowest E, A, $g_{\mathrm{S}}$, and RDI had the lowest WUE. The irrigation plus-PFT treatments had significantly lower $\mathrm{E}$ and $g_{\mathrm{S}}$ compared with the non-PFT treatments, but there was no irrigation plus-PFT effect on A or WUE.

Post-prolonged deficit stress period 3 Feb. 2004. There was an interaction of irrigation treatment with PFT on WUE in which plus-PFT increased WUE of the PD treatment but decreased WUE of the RDI treatment. There were no significant irrigation treatment effects on E, A, or $g_{\mathrm{S}}$. Plus-PFT reduced $g_{\mathrm{S}}$ $(P=0.08)$ compared with non-PFT.

Leaf isotopic carbon discrimination $(\Delta)$ data collected on 9 Jan. 2004 indicated no significant differences resulting from irrigation $(27.1,26.8$, and 26.8 for STD, RDI, and $\mathrm{PD}$, respectively) or PFT treatment (27.0 and
26.9 for plus-PFT versus non-PFT, respectively). However, by 18 Mar., the PFT treatment, pooled over irrigation treatments, had significantly $(P=0.05)$ lower $\Delta$ than the non-PFT (27.6 versus 28.0, respectively), indicating an increased water use efficiency in PFT treatments (Bacon, 2004; Gibberd et al., 2001). RDI, PD, and STD did not significantly differ in leaf $\Delta(27.7,27.7$, and 28.1 , respectively; $P=0.40$ ). There was no irrigation $\times$ PFT treatment interaction at either date.

'Merlot' and 'Viognier', Parma, ID, 2005. Irrigation regime had a greater influence than PFT on leaf water potential, surface temperature, gas exchange, and yield components and the effect of PFT on some of these attributes differed according to irrigation regime and or cultivar.

Vine water status. The $\Psi_{\mathrm{md}}$ of vines corresponded with irrigation regime throughout the growing season (Fig. 2). The $\Psi_{\text {md }}$ of vines under $100 \% \mathrm{ET}_{\mathrm{c}}$ was lower than -1.0 $\mathrm{MPa}$ on several occasions during the season suggesting that on these occasions, the estimated $\mathrm{ET}_{\mathrm{c}}$ was less than actual $\mathrm{ET}_{\mathrm{c}}$ and that irrigation amount was insufficient to meet vine demand (Greenspan, 2005; Shellie, 2006). Before veraison, vines under PD had significantly lower $\Psi_{\text {md }}$ than vines under 
STD in 4 of 5 weeks. The week after the irrigation amount was increased to $70 \% \mathrm{ET}_{\mathrm{c}}$ (23 Aug.) for the PD treatment, $\Psi_{\mathrm{md}}$ increased to a level similar to vines under STD irrigation. Differences in $\Psi_{\mathrm{md}}$ were more frequently observed between irrigation treatments than between plus-PFT or nonPFT vines within each irrigation treatment. The $\Psi_{\mathrm{md}}$ of vines with PFT under STD irrigation was significantly higher $50 \%$ of the times that each cultivar was measured. However, vines with plus-PFT under PD had similar ('Merlot') or lower ('Viognier') $\Psi_{\text {md }}$ two of five times the vines were measured before veraison. These different cultivar and irrigation responses to PFT were also apparent in the diurnal measurements of $\Psi$ (Fig. 3).
Plant water relations and water use efficiency. Diurnal leaf surface temperature was also more influenced by irrigation regime than by PFT and response to PFT differed by irrigation regime and cultivar (Fig. 3). The leaf surface temperature of vines under STD was cooler than vines under $\mathrm{PD}$, and the maximum difference in leaf surface temperature between irrigation regimes (2.7 and $2.9{ }^{\circ} \mathrm{C}$ for 'Viognier' and 'Merlot', respectively) was almost twice as large as the difference between plus-PFT and non-PFT vines within each irrigation regime (1.7 and $1.5^{\circ} \mathrm{C}$ for $\mathrm{PD}$ and STD, respectively). The maximum difference in leaf surface temperature between plus-PFT and non-PFT vines occurred $1 \mathrm{~h}$ earlier in vines

Table 1. Mean shaded leaf water potential measured with leaf psychrometers from 1000 to $1600 \mathrm{HR}$ in the pre-veraison and post-veraison periods for 'Cabernet Sauvignon' grape (Vitis vinifera L.) in Sunraysia, Australia, grown under standard (STD), regulated deficit irrigation (RDI), or prolonged deficit (PD) irrigation with particle film treatment (plus-PFT) or without particle film treatment (non-PFT) in 2004.

\begin{tabular}{|c|c|c|c|c|}
\hline \multirow{3}{*}{$\begin{array}{l}\text { Irrigation } \\
\text { treatment }\end{array}$} & \multicolumn{4}{|c|}{ Shaded leaf water potential } \\
\hline & \multicolumn{2}{|c|}{ Pre-veraison period (pre 18 Jan. 2004) } & \multicolumn{2}{|c|}{ Post-veraison period (post 18 Jan. 2004) } \\
\hline & Plus-PFT (MPa) & Non-PFT (MPa) & Plus-PFT (MPa) & Non-PFT (MPa) \\
\hline$\overline{\text { STD }}$ & $-0.50 \mathrm{~b}^{\mathrm{z}}$ & $-0.54 \mathrm{~b}$ & $-0.21 \mathrm{a}$ & $-0.45 \mathrm{~b}$ \\
\hline RDI & $-0.55 \mathrm{~b}$ & $-0.62 \mathrm{c}$ & $-0.48 \mathrm{~b}$ & $-0.74 \mathrm{c}$ \\
\hline $\mathrm{PD}$ & $-0.46 \mathrm{a}$ & $-0.51 \mathrm{ab}$ & $-0.46 \mathrm{~b}$ & $-0.63 \mathrm{c}$ \\
\hline
\end{tabular}

${ }^{\mathrm{z}}$ Mean separation within time periods by protected least significant difference $(P=0.05)$.

under PD irrigation [at $2 \mathrm{~h}(\mathrm{PD})$ rather than $3 \mathrm{~h}$ (STD) after solar noon] and persisted longest under STD. Plus-PFT vines under STD were cooler than non-PFT vines in $75 \%$ ('Merlot') or $80 \%$ ('Viognier') of hourly readings, whereas vines with plus-PFT under $\mathrm{PD}$ irrigation were cooler than non-PFT vines in $67 \%$ ('Viognier') or $68 \%$ ('Merlot') of the hourly readings. Vines under STD had higher $\Psi$ and $g_{\mathrm{S}}$ than vines under PD irrigation (Fig. 3). Particle film had less impact on diurnal $\Psi$ and $g_{S}$ than irrigation regime, and its effect on both of these measurements varied by irrigation regime and by cultivar, similar to Rosati et al. (2006). Vines under STD with plus-PFT had higher $\Psi$ and lower $g_{S}$ before noon than non-PFT vines. The $\Psi$ of 'Merlot' vines with plus-PFT under STD irrigation remained higher $2 \mathrm{~h}$ longer than 'Viognier' vines. In the afternoon, plus-PFT vines under STD irrigation had higher $g_{\mathrm{S}}$ for $2 \mathrm{~h}$ and similar leaf water potential as non-PFT vines. Vines under PD irrigation with particle film had lower ('Viognier') or similar ('Merlot') $\Psi$ and $g_{\mathrm{S}}$ as non-PFT vines. Annual shoot tissue from the PD irrigation treatment had significantly lower $\Delta$ than well-watered vines from the STD (14.5 versus 16.2). Application of particle film had no effect on $\Delta$ in the STD treatment; however, annual shoot tissue

Table 2. Leaf gas exchange and water use efficiency for 'Cabernet Sauvignon' (Vitis vinifera L.) grown in Sunraysia Australia under standard (STD), regulated deficit irrigation (RDI), or prolonged deficit or without particle film treatment (PFT) in 2003-2004 growing season.

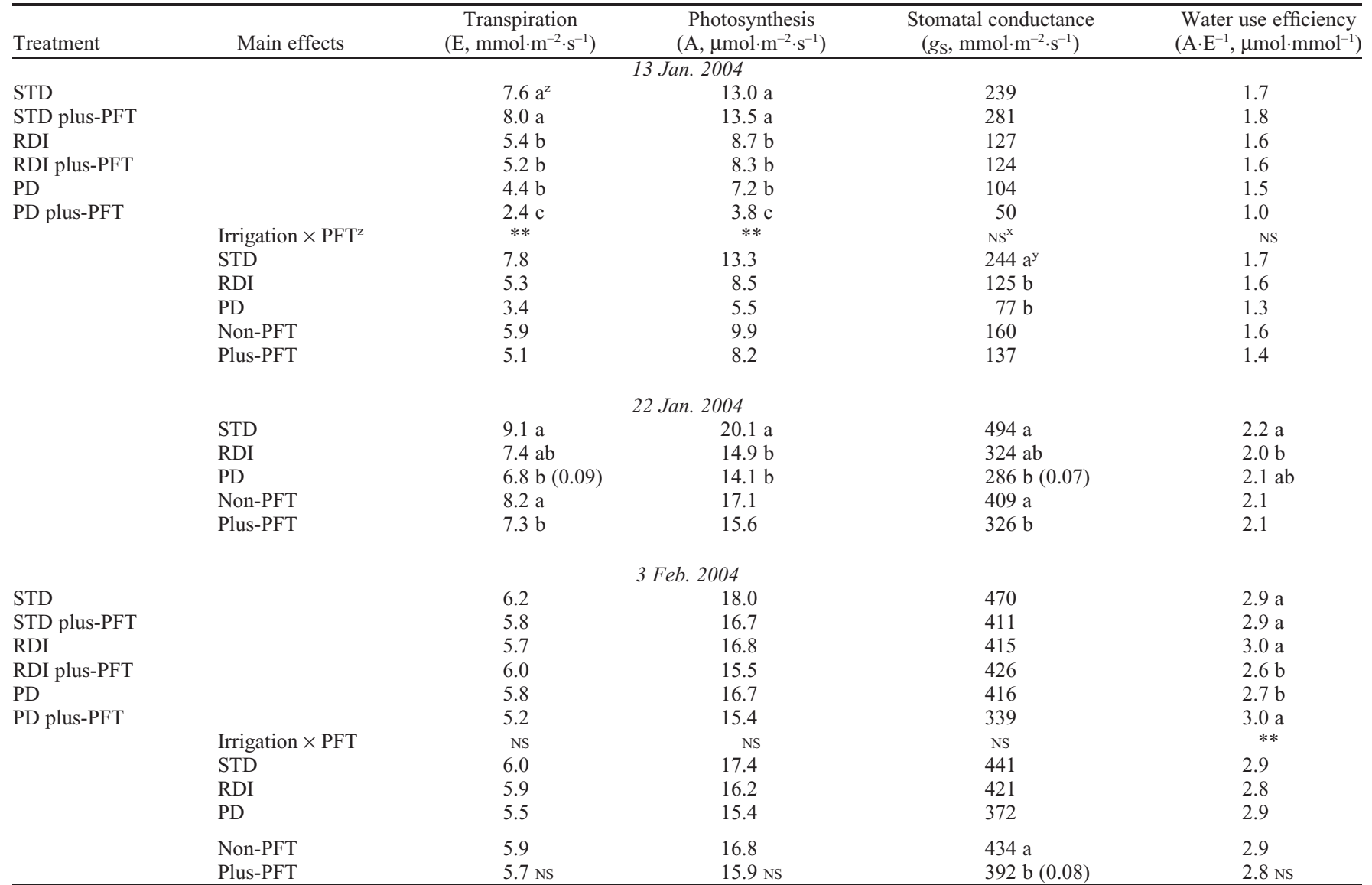

${ }^{\mathrm{z}}$ When an irrigation by PFT interaction was significant $(* *)$, the individual treatments were separated using a protected least significant difference $(P=0.05)$. ${ }^{\mathrm{y}}$ Mean separation within columns for a sampling date by protected least significant difference $(P=0.05)$ unless otherwise specified in brackets.

${ }^{\mathrm{x}}$ Non-significant difference $(P=0.05)$. 
Day of the year

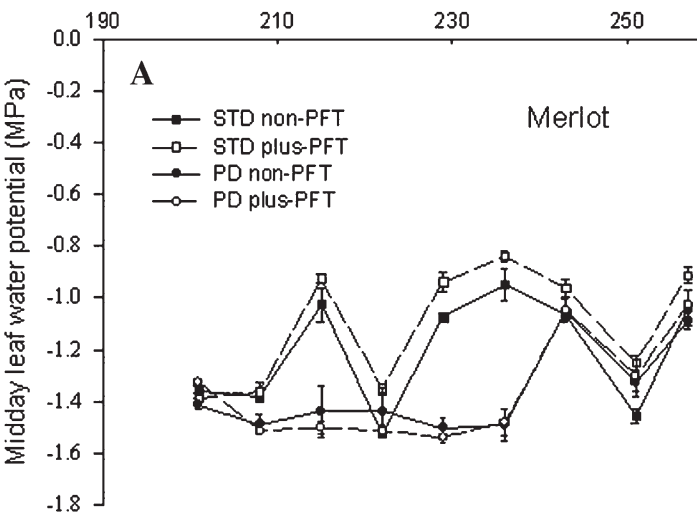

Day of year

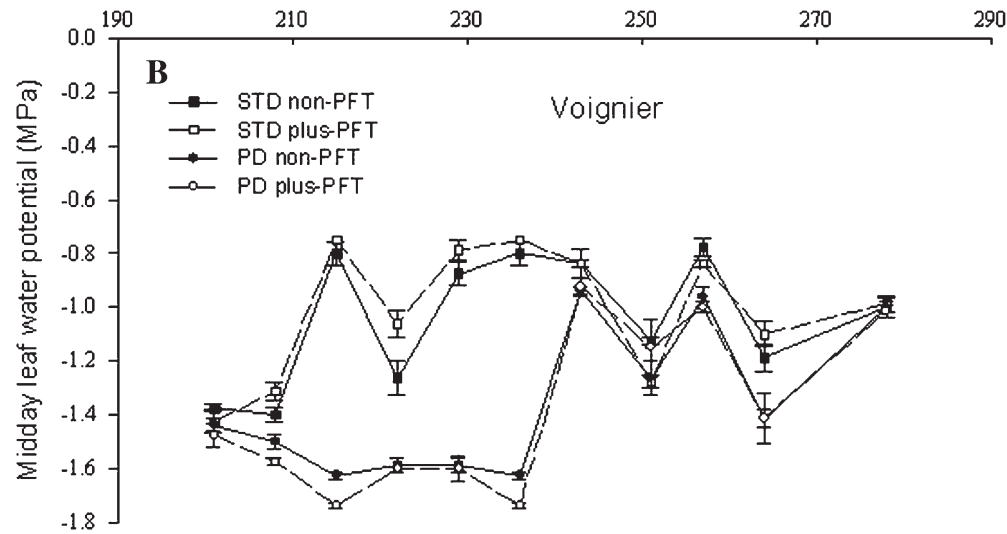

Fig. 2. Midday leaf water potential of 'Merlot' (top) and 'Viognier' (bottom) grown in Parma, ID, under standard (STD) or prolonged deficit (PD) in the 2005 growing season. Measurements were collected $5 \mathrm{~d}$ after weekly irrigation. Veraison day of year was 21 Aug. (DOY = 233) for 'Merlot' and 16 Aug. $(\mathrm{DOY}=228)$ for 'Viognier'.

under PD irrigation treatment with plus-PFT had significantly lower $\Delta$ (13.97) than nonPFT vines $(15.00)(P=0.05)$.

Yield components. Irrigation regime influenced yield components for both cultivars and juice titratable acidity of 'Viognier' (Table 3 ). Plus-PFT increased the cluster weight of 'Viognier' under STD. Vines under PD irrigation had $39 \%$ to $49 \%$ lower yield per vine, $35 \%$ to $32 \%$ lower cluster weight, and $12 \%$ to $15 \%$ lower berry weight than vines under STD irrigation. Most soluble solids concentration and $\mathrm{pH}$ at harvest differed by cultivar but were similar under STD and PD irrigation for each cultivar ( $25 \%$ and 3.4, 22\% and 3.1 for 'Merlot' and 'Viognier', respectively). Juice titratable acidity of 'Viognier' grown under PD irrigation was lower than vines grown under STD irrigation. The cluster weight of 'Viognier' vines grown under STD irrigation plus-PFT was $\approx 15 \%$ greater than non-PFT vines, but this trend was not observed in 'Merlot' vines.

\section{Discussion}

Plant water relations were more impacted by irrigation regime than by particle film; however, vines with kaolin-particle film had the coolest leaf and canopy temperature. Vines under deficit irrigation had the warmest leaf and canopy temperature, lowest $\Psi$, lowest $g_{\mathrm{S}}$ and the highest WUE. Vine capacity for transpirational cooling was impaired because maximum daily air temperature increased under deficit irrigation (Figs. 1 and 3 ). This trend was especially apparent in 'Cabernet Sauvignon' under PD irrigation in which $\Delta \mathrm{T}$ exceeded maximum daily ambient temperature and by the larger, more negative regression slope of well-watered compared with PD-treated vines (Fig. 1A).

Vines with plus-PFT had the lowest leaf and canopy temperature; temperature differences between plus-PFT and non-PFTtreated vines were most pronounced during the afternoon hours of highest solar radiation and ambient air temperature (Figs. 1B-D and 3). Kaolin-particle film has been shown to selectively reflect IR and ultraviolet radiation (Glenn et al., 2002). A reduction in leaf and fruit temperature by particle film of up to $8^{\circ} \mathrm{C}$ has been reported in apple (Glenn et al., 2001, 2002,2003 ) and up to $5{ }^{\circ} \mathrm{C}$ in grapefruit (Jifon and Syvertsen, 2003). The cooler surface temperature associated with particle film results in a smaller leaf to air vapor pressure deficit and, through feedforward control of evaporative demand on $g_{\mathrm{S}}$, a decrease in potential transpiration (Rosenberg, 1974). The PFT material has an emissivity similar to plant material, 0.98 (Glenn et al., 2002); emissivity is the fraction of blackbody emission, at a given wavelength, emitted by a surface.

Deficit irrigated vines had lower leaf water potential (Table 1; Figs. 2 and 3 ) and lower $g_{\mathrm{S}}$ (Fig. 3; Table 2) than well-watered vines. Lu et al. (2003) suggested that vine canopy conductance under well-watered conditions displays typical feedforward control, showing strong responsiveness to changes in ambient evaporative demand. However, Tenhuen et al. (1982) showed that midday stomatal closure occurs under high transpirational demand despite adequate soil water availability. Boland et al. (2000a, 2000b) have shown in peach that deficit irrigation can restrict root volume and that restricted root volume was associated with a reduction in vegetative growth and canopy transpiration demand. Cooley et al. (2004) reported up to $17 \%$ reduction in leaf area and $40 \%$ reduction in shoot growth in 'Cabernet Sauvignon' under deficit irrigation and Shellie (2006) reported an increase in canopy light transmission under deficit irrigated 'Merlot'. The reduction in $g_{S}$ observed in this study under deficit irrigation regimes was most likely the result of negative feedback of low plant water status. Plant water status, at any point in time, is influenced by prior water status conditions that may have altered root capacity for water uptake, xylem hydraulic conductivity, non-hydraulic signals (Soar et al., 2004), and/or the ratio of shoot to root transpiration demand.

In this study, the post-veraison SLWP of 'Cabernet Sauvignon' vines under PD or RDI remained significantly lower than well-watered vines even after the irrigation amount was increased (Table 1). However, the $\Psi_{\text {md }}$ of 'Viognier' and 'Merlot' vines increased within 1 week after irrigation amount was increased post-veraison. Because SLWP was not measured in these vines, it is unclear whether persistence of low leaf water potential in 'Cabernet Sauvignon' could be attributed to measurement technique or differences in cultivar or growing conditions. High levels of water stress have been shown to induce xylem cavitation, decrease xylem conductance (Clark and Gibbs, 1957; Hacke and Sperry, 2003; Tyree and Sperry, 1989), and impair the ability of the plant to meet its transpirational demand after irrigation is resumed. Schultz (2003) used acoustic emission to detect xylem embolism in Vitis vinifera L. cv. Grenache petioles that had a pre-dawn leaf water potential of $-1.2 \mathrm{MPa}$ and Hacke and Sperry (2003) have shown that there are limits to xylem refilling after induction of embolism. It is possible that the level of water stress in 'Cabernet Sauvignon' may have induced xylem cavitation and therefore inhibited recovery on rewatering. Leaf water potential measured with thermocouple psychrometers are thought to be equivalent to that measured with a pressure chamber (Brown and Tanner, 1981; Campbell and Campbell, 1974; Liu et al., 1978). However, it is possible that stomatal recovery from water stress may be more delayed than recovery of leaf water potential (Jones, 1986) and that the 

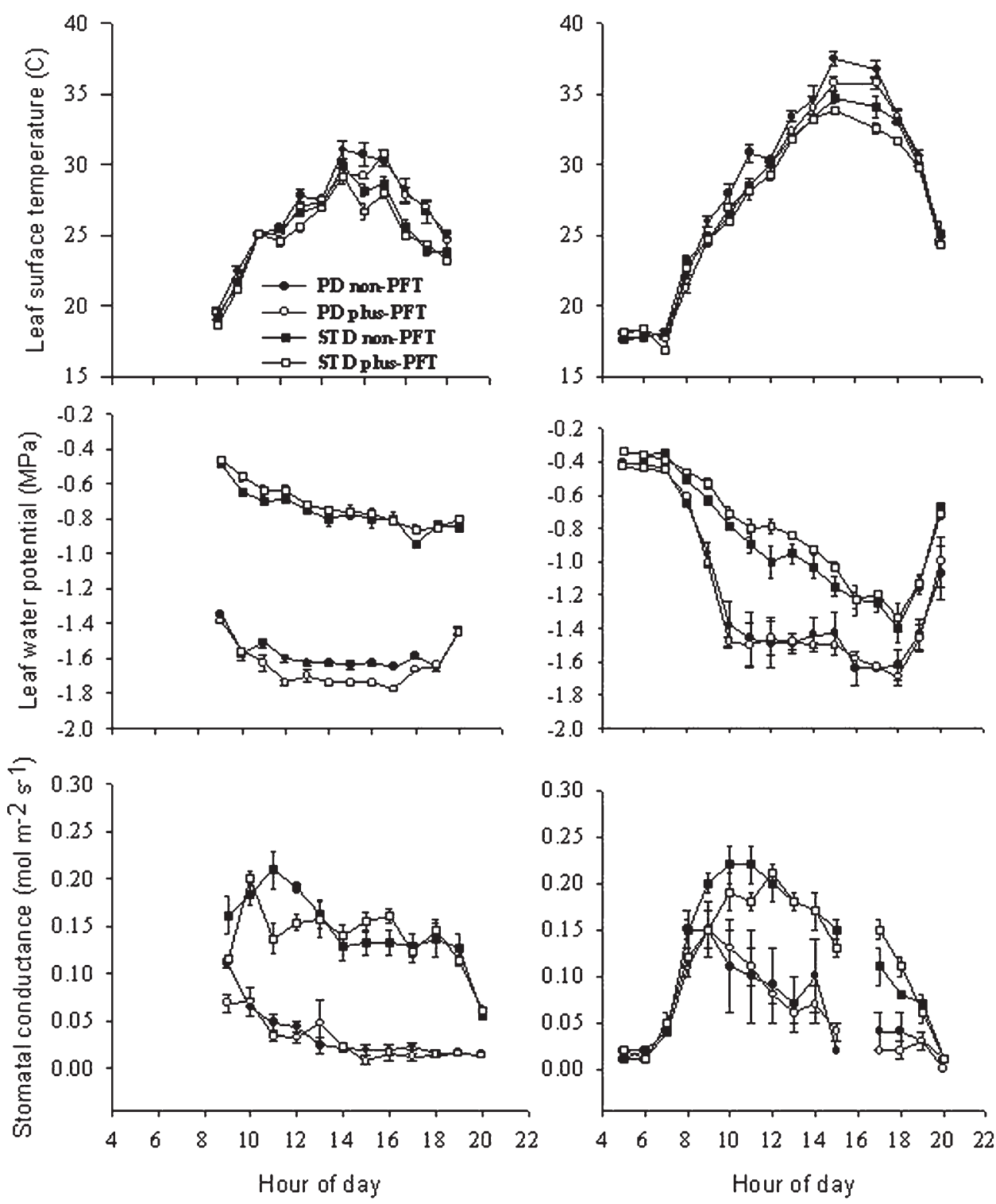

Fig. 3. Diurnal variation of leaf surface temperature, water potential, and stomatal conductance $\left(g_{\mathrm{S}}\right)$ for standard (STD) and prolonged deficit (PD) irrigation with and without particle film treatments (PFT) in 'Viognier' and 'Merlot' grown in Parma, ID.

Table 3. Titratable acidity and yield components of 'Merlot' and 'Viognier' under standard (STD) or prolonged deficit (PD) irrigation regimes with (plus-PFT) or without (non-PFT) particle film treatment in Parma, ID.

\begin{tabular}{|c|c|c|c|c|c|c|c|c|c|}
\hline \multirow[b]{3}{*}{ Treatment } & \multicolumn{4}{|c|}{ 'Merlot'y } & \multicolumn{5}{|c|}{ 'Viognier' } \\
\hline & \multirow{2}{*}{$\begin{array}{c}\text { Titratable } \\
\text { acidity }\left(\mathrm{g} \cdot \mathrm{L}^{-1}\right)\end{array}$} & \multirow{2}{*}{$\begin{array}{l}100 \text { Berry } \\
\text { wt }(g)\end{array}$} & \multirow{2}{*}{$\begin{array}{l}\text { Cluster } \\
\text { wt (g) }\end{array}$} & \multirow{2}{*}{$\begin{array}{l}\text { Yield per } \\
\text { vine }(\mathrm{kg})\end{array}$} & \multirow{2}{*}{$\begin{array}{c}\text { Titratable } \\
\text { acidity }\left(\mathrm{g} \cdot \mathrm{L}^{-1}\right)\end{array}$} & \multirow{2}{*}{$\begin{array}{c}100 \text { bBerry } \\
\text { wt (g) }\end{array}$} & \multicolumn{2}{|c|}{ Cluster wt } & \multirow{2}{*}{$\begin{array}{l}\text { Yield per } \\
\text { vine }(\mathrm{kg})\end{array}$} \\
\hline & & & & & & & plus-PFT (g) & non-PFT (g) & \\
\hline STD & 5.2 & $116.2 \mathrm{a}$ & $103.2 \mathrm{a}$ & $3.1 \mathrm{a}$ & $0.91 \mathrm{a}$ & $102.6 \mathrm{a}$ & $138.6 \mathrm{a}$ & $120.9 \mathrm{~b}$ & $5.3 \mathrm{a}$ \\
\hline Irrigation & $\mathrm{NS}^{\mathrm{x}}$ & NS & $* *$ & $*$ & $* *$ & $* *$ & \multicolumn{2}{|c|}{ ** } & $*$ \\
\hline PFT & NS & NS & NS & NS & NS & NS & \multicolumn{2}{|c|}{ * } & NS \\
\hline Irrigation* $\mathrm{PFT}^{\mathrm{z}}$ & NS & NS & NS & NS & NS & NS & \multicolumn{2}{|c|}{ * } & NS \\
\hline
\end{tabular}

${ }^{2}$ When an irrigation by PFT interaction was significant $(* *)$, the individual treatments were separated using a protected least significant difference $(P=0.05)$.

${ }^{\mathrm{y}}$ Mean separation within columns for a cultivar by protected least significant difference $(P=0.05)$.

${ }^{\mathrm{x}}$ Non-significant difference $(P=0.05)$.

thermocouple psychrometers used to measure SLWP were more sensitive to stomatal activity than the pressure chamber used to measure $\Psi_{\mathrm{md}}$.

Particle film altered the levels of $\Psi$ and $g_{\mathrm{S}}$ (Table 1; Fig. 3) and the greatest effect was observed in well-watered vines. For example, under deficit irrigation with particle film, $\Psi$ and $g_{\mathrm{S}}$ of 'Merlot' and 'Viognier' vines were similar to vines without particle film despite cooler leaf surface temperature. These data suggest that under deficit irrigation, stomatal responsiveness to feedforward control from lower evaporative demand, resulting from the particle film reduction in leaf temperature, was limited by the negative feedback control of low plant water status. 'Viognier' had lower $\Psi$ than 'Merlot' and was also 30\% lower than 'Cabernet Sauvignon', suggesting a cultivar difference in stomatal responsiveness to plant water status. This difference in $\Psi$ cannot be explained by differences in canopy size because the canopy of 'Viognier' was smaller and less dense than 'Merlot' (data not shown). 
The relationship of transpiration $(\mathrm{E}), g_{\mathrm{S}}$, and canopy-air temperature $(\Delta \mathrm{T})$ can be expressed as a modification of Fick's law by:

$$
\mathrm{E}=\mathrm{g}_{\mathrm{s}}(0.622 p \mathrm{a} / \mathrm{P})[\mathrm{\delta e}+\mathrm{s}(\Delta \mathrm{T})]
$$

where, $p \mathrm{a}=$ the density of dry air, $\mathrm{P}=$ atmospheric pressure, $\delta \mathrm{e}=$ water vapor pressure deficit, and $\mathrm{s}=$ slope of the curve relating saturation vapor pressure to temperature (Jones, 1986).

Similarly, E has a proportional $(\alpha)$ relationship with $g_{\mathrm{S}}$ and the difference in vine water potential $(\triangle \mathrm{LWP})$ from the root-soil interface to the leaf-air interface (Jones, 1986):

$$
\mathrm{E} \alpha \mathrm{g}_{\mathrm{s}}(\Delta \mathrm{LWP})
$$

When particle film reduces leaf temperature (Glenn and Puterka, 2005), $\Delta \mathrm{T}$ declines (Figs. 1 and 3), reducing the vapor pressure deficit and therefore $\mathrm{E}$ and $g_{\mathrm{S}}$ (Table 2; Fig. 3, bottom). Reduction in $\mathrm{E}$ and $g_{\mathrm{S}}$ (Eq. 2) facilitates a decrease in $\triangle \mathrm{LWP}$, as demonstrated in the field study of SLWP (Table 1; Figs. 2 and 3). Although these relationships are related to illuminated leaves, Chone et al. (2001) have demonstrated that the stem water potential gradient (similar to SLWP) is also directly related to $\mathrm{E}$.

Isotopic carbon discrimination $(\Delta)$ is highly negatively correlated to WUE (Bacon, 2004; Bongi et al., 1994; Condon et al., 1990; Gibberd et al., 2001; Glenn et al., 2000, 2006; Jones, 2004) and reduced $g_{\mathrm{S}}$ is a key mechanism of increasing WUE (Bacon, 2004). 'Cabernet Sauvignon' vines treated with particle film had no significant effect on $\Delta$ at the 9 Jan. sampling date despite the application of PFT treatments on 28 Nov. and 12 Dec. nor were there gas exchange responses to suggest a WUE response through 13 Jan. (Table 2). The components of increased WUE appeared to develop with plus-PFT treatment after $\approx 2$ months of treatment. By 22 Jan., $g_{\mathrm{S}}$ was significantly lower for plus-PFT treatments overall irrigation treatments (Table 2) and at the 3 Feb. sampling date, the plus-PFT PD and plus-PFT RDI treatments had a significantly higher WUE than the non-PFT treatments (Table 2). By 18 Mar., 'Cabernet Sauvignon' vines treated with particle film had a significant reduction in $\Delta$, suggesting enhanced seasonal WUE independent of irrigation regime. Plus-PFT treatment was associated with a reduction in shoot $\Delta$ in 'Merlot' and 'Viognier' vines only under deficit irrigation in which point-in-time measurement of $g_{\mathrm{S}}$ was similar to non-particle film vines. The value of $\Delta$ lies in the integration of seasonal responses to the environment rather than point-in-time responses measured in diurnal studies (Table 2) (Glenn, 2010). The differences in magnitude of $\Delta$ between trial sites in Australia and Idaho are because leaf tissue was sampled in Victoria, whereas shoot tissue was sampled in Idaho.

Particle film application had no significant impact on yield and appeared to have cultivar-specific effects on soluble solids, titratable acidity, and cluster size. The soluble solids content of non-PFT-treated 'Caber- net Sauvignon' berries was marginally but significantly higher than plus-PFT-treated vines (23.8 and 24.2 ${ }^{\circ}$ Brix, respectively, $P<0.01)$; however, this difference was not observed in 'Merlot' or 'Viognier' (Table 3). TSS is an indicator of fruit maturity. All fruit reached commercial maturity, suggesting that net photosynthesis within an irrigation treatment was sufficient to ripen fruit to maturity despite reduced $g_{\mathrm{S}}$. These results also suggest that cultivars respond differently to PFT treatments. Shellie and Glenn (2008) demonstrated that PFT treatments were associated with an increase in berry weight in 'Merlot' and with an increase in berry soluble solids concentration in 'Viognier', suggesting that the film may increase vine-carrying capacity.

Regulated deficit irrigation is a significant improvement in water management for horticultural crops because it reduces irrigation water inputs while improving crop quality. The reduction of vegetative growth by managed water deficits is highly effective in improving grape quality (Jackson and Lombard, 1993). The present study suggests that particle film application can further enhance the WUE of RDI through a reduction in leaf surface temperature. The observed discrepancies between point-in-time measurements and seasonal $\Delta$ highlight how effects of water deficits persist throughout the growing season (Glenn, 2010).

To conclude, the negative linear relationship between $\Delta \mathrm{T}$ and the MDAT indicates greater transpirational cooling at high temperatures. Irrigation treatments had more of an effect on the relationship between $\Delta \mathrm{T}$ and MDAT than did application of a particle film. Vines with particle film had a cooler canopy temperature, resulting in a more negative $\Delta \mathrm{T}$ resulting from physical reflection of IR radiation from the leaf surface similar to Glenn et al., $(2001,2002,2003)$ in apple. Application of particle film tended to reduce $g_{\mathrm{S}}$ throughout the season. The ability of vines treated with particle film to undergo stomatal closure and to increase leaf water potential assisted the vines to conserve water and increase WUE (Eq. 2). The contribution of particle film to the seasonal WUE of deficit irrigation treatments varies by cultivar and irrigation regime.

\section{Literature Cited}

Allen, R.G., L.S. Pereira, D. Raes, and M. Smith. 1998. Crop evapotranspiration - Guidelines for computing crop water requirements. FAO Irrigation and drainage paper 56. Food and Agriculture Organization of the United Nations, Rome, Italy.

Bacon, M.A. 2004. Water use efficiency in plant biology, p. 1-22. In: Bacon, M.A. (ed.). Water use efficiency in plant biology. CRC Press, Boca Raton, FL.

Begg, J.E. and N.C. Turner. 1970. Water potential gradients in field tobacco. Plant Physiol. 46:343-346.

Boland, A.M., P.H. Jerie, P.D. Mitchell, I. Goodwin, and D.J. Connor. 2000a. Long-term effects of restricted root volume and regulated deficit irrigation on peach: I. Growth and mineral nutrition. J. Amer. Soc. Hort. Sci. 125:135142.

Boland, A.M., P.H. Jerie, P.D. Mitchell, I. Goodwin, and D.J. Connor. 2000b. Long-term effects of restricted root volume and regulated deficit irrigation on peach: II. Productivity and water use. J. Amer. Soc. Hort. Sci. 125:143148.

Boland, A.M., P.D. Mitchell, P.H. Jerie, and I. Goodwin. 1993. The effect of regulated deficit irrigation on tree water use and growth of peach. J. Hort. Sci. 68:261-274.

Bongi, G., A. Palliotti, P. Rocchi, and G. Roselli. 1994. Evaluation of WUE in peach grafted on different interspecific hybrid rootstocks. Plant Physiol. Biochem. 32:149-157.

Bota, J., J. Flexas, and H. Medrano. 2001. Genetic variability of photosynthesis and water use in Balearic grapevine cultivars. Ann. Appl. Biol. 138:353-361.

Brown, P.W. and C.B. Tanner. 1981. Alfalfa water potential measurement: A comparison of the pressure chamber and leaf dew-point hygrometers. Crop Sci. 21:240-244.

Buttrose, M.S. 1974. Fruitfulness in grapevines: Effects of water stress. Vitis 12:299-305.

Campbell, C.S. and K.J. McInnes. 1999. Response of in situ leaf psychrometer to cuticle removal by abrasion. Agron. J. 91:859-862.

Campbell, G.S. and M.D. Campbell. 1974. Evaluation of a thermocouple hygrometer for measuring leaf water potential in situ. Agron. J. $74: 24-27$

Castellarin, S.D., A. Pfeiffer, P. Sivilotti, M. Degan, E. Peterlunger, and G. Di Gaspero. 2007. Transcriptional regulation of anthocyanin biosynthesis in ripening fruits of grapevine under seasonal water deficit. Plant Cell Environ. 30:1381-1399.

Chalmers, D.J., P.D. Mitchell, and L. van Heek. 1981. Control of peach growth and productivity by regulated water supply, tree density and summer pruning. J. Amer. Soc. Hort. Sci. 106: 307-312.

Chapman, D.M., G. Roby, S.E. Ebeler, J. Guinard, and M.A. Matthews. 2005. Sensory attributes of Cabernet Sauvignon wines made from vines with different water status. Aust. J. Grape Wine Res. 11:339-347.

Chone, X., C. van Leeuwen, D. Dubourdieu, and J.P. Gaudillere. 2001. Stem water potential is a sensitive indicator of grapevine water status. Ann. Bot. (Lond.) 87:477-483.

Clark, J. and R.D. Gibbs. 1957. Studies in tree physiology. IV. Further investigations of seasonal content of certain Canadian forest trees: Can. J. Bot. 35:219-253.

Condon, A.G., G.D. Farquhar, and R.A. Richards. 1990. Genotypic variation in carbon-isotope discrimination and transpiration efficiency in wheat: Leaf gas exchange and whole plant studies. Aust. J. Plant Physiol. 17:9-22.

Cooley, N.M., P.R. Clingeleffer, and R.R. Walker. 2004. The balance of berry sugar accumulation, colour and phenolic concentration under deficit irrigation strategies, p. 94-96. In: Blair, R., P. Williams, and S. Pretorious (eds.). Proc. 12th Australian Wine Industry Technical Conference. Melbourne, Australia, Australian Wine Industry Technical Conference Inc., Urrbrae, South Australia.

Cortell, J.M., M. Halbleib, A.V. Gallagher, T.L. Righetti, and J.A. Kennedy. 2005. Influence of vine vigor on grape (Vitis vinifera L. cv. Pinot Noir) and wine proanthocyanidins. J. Agr. Food Chem. 53:5798-5808.

El-Ansary, D.O. and G. Okamoto. 2007. Vine water relations and quality of 'Muscat of 
Alexandria' table grapes subjected to partial root-zone drying and regulated deficit irrigation. J. Jpn. Soc. Hort. Sci. 76:13-19.

Esteban, M.A., M.J. Villanueva, and J.R. Lissarrague. 1999. Effect of irrigation on changes in berry composition of tempranillo during maturation. Sugars, organic acids, and mineral elements. Amer. J. Enol. Viticult. 50:418-434.

Evans, R.G., S.E. Spayd, R.L. Wample, M.W. Kroeger, and M.O. Mahan. 1993. Water use of Vitis vinifera grapes in Wash. Agr. Water Manage. 23:109-124.

Farquhar, G.D., J.R. Ehleringer, and K.T. Hubick. 1989. Carbon isotope discrimination and photosynthesis. Ann. Rev. Plant Physiol. Mol. Biol. 40:503-537.

Francey, U.J., P.P. Tans, C.E. Allison, I.G. Enting, J.W.C. White, and M. Troller. 1995. Changes in oceanic and terrestrial carbon uptake since 1982. Nature 373:326-330.

Gibberd, M.R., R.R. Walker, D.H. Blackmore, and A.G. Condon. 2001. Transpiration efficiency and carbon isotope discrimination of grapevines grown under well-watered conditions in either glasshouse or vineyard. Aust. J. Grape Wine Res. 7:110-117.

Girona, J., M. Mata, A. Arones, S. Alegre, J. Rufat, and J. Marsal. 2003. Peach tree response to single and combined regulated deficit irrigation regimes under shallow soils. J. Amer. Soc. Hort. Sci. 128:432-440.

Girona, J., M. Mata, D.A. Goldhamer, R.S. Johnson, and T.M. DeJong. 1993. Patterns of soil and tree water status and leaf functioning during regulated deficit irrigation scheduling in peach. J. Amer. Soc. Hort. Sci. 118:580586.

Glenn, D.M. 2009. Particle film mechanisms of action that reduce the effect of environmental stress in 'Empire' apple. J. Amer. Soc. Hort. Sci. 134:314-321.

Glenn, D.M. 2010. Canopy gas exchange and water use efficiency of 'Empire' apple in response to particle film, irrigation, and microclimatic factors. J. Amer. Soc. Hort. Sci. 135:25-32.

Glenn, D.M., R. Scorza, and W.R. Okie. 2006. Genetic and environmental effects on water use efficiency in peach. J. Amer. Soc. Hort. Sci. 131:290-294.

Glenn, D.M., A. Erez, G.J. Puterka, and P. Gundrum. 2003. Particle films affect carbon assimilation and yield in 'Empire' apple. J. Amer. Soc. Sci. 128:356-362.

Glenn, D.M., E. Prado, A. Erez, J. McFerson, and G.J. Puterka. 2002. A reflective, processedkaolin particle film affects fruit temperature, radiation reflection, and solar injury in apple. J. Amer. Soc. Hort. Sci. 127:188-193.

Glenn, D.M. and G.J. Puterka. 2005. Particle films: A new technology for agriculture. HortRev. 31:1-44.

Glenn, D.M., G.J. Puterka, S.R. Drake, T.R. Unruh, P. Baherele, E. Prado, and T. Baugher. 2001. Particle film application influences apple leaf physiology, fruit yield, and fruit quality. J. Amer. Soc. Hort. Sci. 126:175-181.

Glenn, D.M., R. Scorza, and C. Bassett. 2000. Physiological and morphological traits associated with increased water use efficiency in the willow-leaf peach. HortSci. 35:1241-1243.

Goldhamer, D.A. and E. Fereres. 2001. Simplified tree water status measurements can aid almond irrigation. Calif. Agr. 55:32-37.

Goldhamer, D.A., M. Salinas, C. Crisosto, K.R. Day, M. Soler, and A. Moriana. 2002. Effects of regulated deficit irrigation and partial root zone drying on late harvest peach tree performance. Acta Hort. 592:343-350.
Greenspan, M. 2005. Integrated irrigation of California winegrapes. Practical Winery \& Vineyard Sept-Oct.:61-67.

Greven, M., S. Green, S. Neal, B. Clothier, M. Neal, G. Dryden, and P. Davidson. 2005. Regulated deficit irrigation (RDI) to save water and improve Sauvignon Blanc quality? Water Sci. Technol. 51:9-17.

Hacke, U.G. and J.S. Sperry. 2003. Limits to xylem refilling under negative pressure in Laurus nobilis and Acer negundo. Plant Cell Environ. 26:303-311.

Hardie, W.J. and J.A. Considine. 1976. Response of grapes to water-deficit stress in particular stages of development. Am. J. Vit. Enol. 27:55-61.

Hardie, W.J. and S.R. Martin. 1990. A strategy for vine growth regulation by soil water management, p. 51-67. In: Proc. of the Seventh Australian Wine Industry Technical Conference. Adelaide, SA. Australian Wine Industry Technical Conference Inc., Adelaide SA, Australia.

Hepner, Y., B. Bravdo, C. Loinger, S. Cohen, and H. Tabacman. 1985. Effect of drip irrigation schedules on growth, yield, must composition and wine quality of Cabernet Sauvignon. Amer. J. Enol. Viticult. 36:77-85.

Hrazdina, G., G.F. Parsons, and L.R. Mattick. 1984. Physiological and biochemical events during development and maturation of grape berries. Amer. J. Enol. Viticult. 35:220-227.

Jackson, D.I. and P.B. Lombard. 1993. Environmental and management practices affecting grape composition and wine quality-A review. Amer. J. Enol. Viticult. 44:409-430.

Jackson, R.D. 1982. Canopy temperature and crop water stress. Adv. Irrig. 1:43-85.

Jifon, J.L. and J.P. Syvertsen. 2003. Kaolin particle film applications can increase photosynthesis and water use efficiency of 'RubyRed' grapefruit leaves. J. Amer. Soc. Hort. Sci. 128:107112.

Johnson, R.S., D.F. Handley, and T.M. DeJong. 1992. Long-term response of early maturing peach trees to postharvest water deficits. J. Amer. Soc. Hort. Sci. 117:881-886.

Jones, H. 2004. What is water use efficiency? p. 2740. In: Bacon, M.A. (ed.). Water use efficiency in plant biology. CRC Press, Boca Raton, FL.

Jones, H.G. 1986. Plants and microclimate: A quantitative approach to environmental plant physiology. Cambridge Univ. Press, New York, NY.

Koundouras, S., V. Marinos, A. Gkoulioti, Y. Kotseridis, and C. Vanleeuwen. 2006. Influence of vineyard location and vine water status on fruit maturation of nonirrigated cv. Agiogitiko (Vitis vinifera L.). Effects on wine phenolic and aroma components. J. Agr. Food Chem. 54:5077-5086.

Kriedemann, P.E. and I. Goodwin. 2003. Irrigation Insites No. 3. Regulated deficit irrigation and partial rootzone drying. Land and Water Australia, ACT, Australia.

Liu, W.T., W. Wenkert, L.H. Allen, Jr., and E.R. Lemon. 1978. Soil-plant water relations in a New York vineyard: Resistances to water movement. J. Amer. Soc. Hort. Sci. 103:226-230.

Lu, P., I.A.M. Yunusa, R.R. Walker, and W.J. Muller. 2003. Regulation of canopy conductance and transpiration and their modeling in irrigated grapevines. Func. Plant Biol. 30:689-698.

Matthews, M.A. and M.M. Anderson. 1988. Fruit ripening in Vitis vinifera L.: Responses to seasonal water deficits. Amer. J. Enol. Viticult. 39:313-320.

Matthews, M.A., M.M. Anderson, and H.R. Schultz. 1987. Phenologic and growth re- sponses to early and late season water deficits in Cabernet franc. Vitis 26:147-160.

McCarthy, M.G. 1997. The effect of transient water deficit on berry development of cv. Shiraz (Vitis vinifera L.). Aust. J. Grape Wine Res. 3:102-108.

Medrano, H., Escalona, J.M., Cifre, J. Bota, and J. Flexas. 2003. A ten-year study on the physiology of two Spanish grapevine cultivars under field conditions: Effects of water availability from leaf photosynthesis to grape yield and quality. Func. Plant Biol. 30:607-619.

Meriaux, S., H. Rollin, and P. Rutten. 1979. The effects of drought on the grapevine. I. Studies on Cabernet Sauvignon. Annales Agronomiques 30:553-575.

Mitchell, P.D. and D.J. Chalmers. 1982. The effect of reduced water supply on peach tree growth and yields. J. Amer. Soc. Hort. Sci. 107:853-856.

Mitchell, P.D., B. van den Ende, P.H. Jerie, and D.J. Chalmers. 1989. Response of 'Bartlett' pear to withholding irrigation, regulated deficit irrigation, and tree spacing. J. Amer. Soc. Hort. Sci. 114:15-19.

Moriana, A., F. Orgaz, M. Pastor, and E. Fereres. 2003. Yield responses of a mature olive orchard to water deficits. J. Amer. Soc. Hort. Sci. 128:425-431.

Ortega-Farias, S., R.S. Mejias, and Y.M. Simunovic. 2008. Effect of different levels of pruning and water application on vegetative growth, yield and berry composition in grapes cv. Cabernet Sauvignon. Agricultura Technica 67:401-413.

Penman, F., J.K. Taylor, P.D. Hooper, and J.J. Marshall. 1939. A soil survey of the Merbein irrigation district, Victoria. Bulletin no.123. Council of Scientific and Industrial Research, Melbourne, Australia

Roby, G., J.F. Harbertson, D.A. Adams, and M.A. Matthews. 2004. Berry size and vine water deficits as factors in winegrape composition: Anthocyanins and tannins. Aust. J. Grape Wine Res. 10:100-107.

Roby, G. and M.A. Matthews. 2004. Relative proportions of seed, skin and flesh, in ripe berries from Cabernet Sauvignon grapevines grown in a vineyard either well irrigated or under water deficit. Aust. J. Grape Wine Res. 10:74-82.

Rogiers, S.Y., J.A. Smith, R. White, M. Keller, B.P. Holzapfel, and J.M. Virgona. 2010. Vascular function in berries of Vitis vinifera $(\mathrm{L}) \mathrm{cv}$. Shiraz. Aust. J. Grape Wine Res. 7:47-51.

Rosati, A., S.G. Metcalf, R.P. Buchner, A.E. Fulton, and B.D. Lampinen. 2006. Physiological effects of kaolin applications in wellirrigated and water-stressed walnut and almond trees. Ann. Bot. (Lond.) 98:267-275.

Rosenberg, N.J. 1974. Microclimate: The biological environment. John Wiley and Sons, New York, NY.

Salon, J.L., C. Chirivella, and J.R. Castel. 2005. Response of cv. Bobal to timing of deficit irrigation in Requena, Spain: Water relations, yield, and wine quality. Amer. J. Enol. Viticult. $56: 1-8$.

Schultz, H.R. 2003. Differences in hydraulic architecture account for near-isohydric and anisohydric behaviour of two field-grown Vitis vinifera $\mathrm{L}$. cultivars during drought. Plant Cell Environ. 26:1393-1405.

Shellie, K. 2006. Vine and berry response of Merlot (Vitis vinifera L.) to differential water stress. Amer. J. Enol. Viticult. 57:514-518.

Shellie, K. and D.M. Glenn. 2008. Wine grape response to foliar particle film under differing levels of pre-veraison water stress. HortScience 43:1392-1397. 
Soar, C.J., J. Speirs, S.M. Maffei, and B.R. Loveys. 2004. Gradients in stomatal conductance, xylem sap ABA and bulk leaf ABA along canes of Vitis vinifera cv. Shiraz: Molecular and physiological studies investigating their source. Func. Plant Biol. 31:659-669.

Tarara, J.M., J. Lee, S.E. Spayd, and C.F. Scagel. 2008. Berry temperature and solar radiation alter acylation, proportion, and concentration of anthocyanin in Merlot grapes. Amer. J. Enol. Viticult. 59:235-247.

Tenhuen, J.D., O.L. Lange, and D. Jahner. 1982. The control by atmospheric factors and water stress of midday stomatal closure in Arbutus unedo growing in a natural macchia. Oecologia 55:165-169.
Tyree, M.T. and J.S. Sperry. 1989. Vulnerability of xylem to cavitation and embolism. Annu. Rev. Plant Physiol. Plant Mol. Biol. 40:19-36.

U.S. Dept. Agric. Soil Conservation Service. 1972. Soil survey of Canyon area, Idaho. U.S. Government Printing Office, Washington, DC.

Wample, R.L. 1996. Issues in vineyard irrigation. Wine East July-Aug:8-21. 